\section{Efficacy of Soil and Foliar-applied Azadirachtin in Combination with and in Comparison to Soil-applied Imidacloprid and Foliar-applied Carbaryl Against Japanese Beetles on Roses}

\author{
Justin M. Vitullo ${ }^{1,2,3}$ and Clifford S. Sadof ${ }^{1}$
}

\begin{abstract}
Additional index words. Popillia japonica, Rosa, systemic insecticide
Summary. This study evaluated azadirachtin and imidacloprid for their ability to reduce injury by Japanese beetles [Popillia japonica (Coleoptera: Scarabaeidae)] on floribunda-type roses (Rosa sp. 'Acadia Sunrise'), either applied to foliage or as a soil drench. Roses were arranged in field plots and exposed to resident adult beetle populations. Insecticides were evaluated in field and laboratory trials. Laboratory assays of leaves collected from plants 14 days after soil applications of azadirachtin were less preferred by adult beetles than those collected from untreated controls. Plants in field trials that received soil treatments of either imidacloprid or azadirachtin had defoliation levels that were $<8 \%$ throughout the entire season, whereas untreated control plants were $20 \%$ defoliated. Addition of foliar sprays to soil applied insecticides provided no added protection to foliage. Rose blooms were more difficult to protect with both foliar and soil-applied insecticides. Bloom injury of untreated controls varied between $20 \%$ and $30 \%$, while plants receiving soil applications of azadirachtin varied between $0.2 \%$ and $18 \%$. Soil applications of imidacloprid provided somewhat better protection of blooms with injury ranging between $0.2 \%$ and $8 \%$. Foliar applications of azadirachtin gave no added protection to blooms of plants treated with imidacloprid. Adding carbaryl foliar treatments every 2 weeks improved control to $<2 \%$ injury, a level that was comparable to weekly application of carbaryl. The potential for using soil-applied azadirachtin to reduce the need for foliar applications of carbaryl in rose gardens is discussed.
\end{abstract}

$\mathrm{T}$ The Japanese beetle is an economically important pest to growers, landscape managers, and homeowners who rely on insecticides to manage the adult beetle and its grubs. Adults feed on foliage, fruits, or flowers of $>300$ species of wild and cultivated plants in 79 families (Potter and Held, 2002), including Rosaceae. Roses provide a useful system for exploring new ways of controlling adult Japanese beetles because both flowers and leaves are highly susceptible to adult feeding. Due to the attraction of floral scents,

Funding was provided by the USDA IR-4 project, Bayer Environmental Science, PBI Gordon, and Valent corporations.

Roses were donated by Bailey Nurseries (St. Paul, MN). This is paper 2005-17819 of the Indiana Agricultural Research Program.

We thank R. Arcinas, M. Pannich, J. Young, and L. Knoblock for technical assistance. Thanks also to R. Foster and T. Gibb (Dept. of Entomology, Purdue University) and M. Jenks (Dept. of Horticulture, Purdue University) for reviewing this manuscript.

${ }^{1}$ Purdue University, Entomology Department, West Lafayette, IN 47907-2089.

${ }^{2}$ Current address: Tropical Research and Education Center, Homestead, FL 33031

${ }^{3}$ Corresponding author. E-mail: justin.vitullo@ gmail.com. flowers are even more preferred by beetles than foliage (Held and Potter, 2004). Due to the long flight period of adult beetles (usually $>8$ weeks), multiple foliar applications of persistent insecticides like carbaryl are typically used to attain satisfactory control of adult beetles on blooms and foliage (Potter and Held, 2002).

With the implementation of the Food Quality Protection Act (FQPA), the U.S. Environmental Protection Agency (EPA) has revoked the registration of some of the common insecticides homeowners used to control Japanese beetles on roses (U.S. EPA, 2003). If the recent cancellation of diazinon for homeowners is indicative of a trend that will spread to the pyrethroids, there will be a strong need to look for alternatives to broad-spectrum foliar-applied pesticides. Studies that evaluate the ability of pesticides to reduce damage on flowers and leaves could provide simultaneous estimates of efficacy on highly preferred and somewhat less preferred plant substrates.

Imidacloprid is one of the most commonly used materials in landscapes because of its activity against leaf beetles (Chrysomelidae) and its long residual toxicity (Sclar and Cranshaw, 1996; Webb et al., 2003). A single systemic application of imidacloprid reduced adelgid (Adelgidae) populations to zero on healthy eastern hemlock trees (Tsuga canadensis) up to $816 \mathrm{~d}$ after the application (Webb et al., 2003) and provided control of aphids (Aphididae) and elm leaf beetle (Pyrralta luteola) on American elm (Ulmus rubra) for 1-2 years (Lawson and Dahlsten, 2003; Sclar and Cranshaw, 1996). When systemically applied to poplar (Populus deltoides and nigra) and silver maple (Acer saccharinum), imidacloprid was toxic to adult Asian long-horned beetles (Anoplophora glabripennis) (Wang et al., 2005). Although soil applications of imidacloprid do not protect Transvaal daisy (Gerbera jamesonii) blooms from western flower thrips (Frankliniella occidentalis) injury (Cloyd and Sadof, 1998), its outstanding ability to protect foliage makes it a good candidate for adult Japanese beetle control on rose leaves.

Despite its utility as a foliar protectant, soil applications of imidacloprid often result in pest outbreaks of tetranychid mites (Tetranychidae) and armored scales (Diaspididae) (Raupp et al., 2004; Rebek and Sadof, 2003; Sclar et al., 1998). Some of these outbreaks can be explained by reported

\begin{tabular}{llll}
\hline $\begin{array}{l}\text { Units } \\
\text { To convert U.S. to SI, } \\
\text { multiply by }\end{array}$ & U.S. unit & SI unit & $\begin{array}{l}\text { To convert SI to U.S., } \\
\text { multiply by }\end{array}$ \\
\hline 0.3048 & $\mathrm{ft}$ & $\mathrm{m}$ & 3.2808 \\
3.7854 & gal & $\mathrm{L}$ & 0.2642 \\
2.5400 & inch(es) & $\mathrm{cm}$ & 0.3937 \\
25.4000 & inch $(\mathrm{es})$ & $\mathrm{mm}$ & 0.0394 \\
1.6093 & mile(s) & $\mathrm{km}$ & 0.6214 \\
28.3495 & $\mathrm{oz}$ & $\mathrm{g}$ & 0.0353 \\
305.1517 & $\mathrm{oz} / \mathrm{ft}^{2}$ & $\mathrm{~g} \cdot \mathrm{m}^{-2}$ & 0.0033 \\
7.4892 & $\mathrm{oz} / \mathrm{gal}$ & $\mathrm{g} \cdot \mathrm{L}^{-1}$ & 0.1335 \\
6.8948 & $\mathrm{psi}$ & $\mathrm{kPa}$ & 0.1450 \\
& & &
\end{tabular}


toxicity of imidacloprid to lady beetles (Coccinelidae), predatory mites (Phytoseiidae), predatory plant bugs (Miridae), and parasitic wasps (Braconidae) (James and Coyle, 2001; James and Vogele, 2001; Sclar et al., 1998; Smith and Krischik, 1999). In contrast, azadirachtin extracted from the neem tree (Azadirachta indica) have fewer documented impacts on nontarget beneficial insects, reducing likelihood of secondary pest outbreaks (Schmutterer, 1990). The primary activity of azadirachtin is to inhibit the development of immature insects to adulthood by interfering with molting (Ladd et al., 1984). Azadirachtin also has repellent and antifeedant properties that are effective deterrents of $>200$ insect species, including adult Japanese beetles (Duthie-Holt et al., 1999; Held et al., 2001; Ladd et al., 1978). Systemic applications of azadirachtin extracts have been shown to affect a variety of pests on different hosts (Arpaia and van Loon, 1993; Nisbet et al., 1993). The systemic activity of azadirachtin can control sucking and root-feeding insects (Isman et al., 1991) as well as reduce boring insects, such as the pine engraver beetle (Ips pini) and the mountain pine beetle (Dendroctonus ponderosae) on lodgepole pine (Pinus contorta) (Duthie-Holt et al., 1999; Naumann et al., 1994). Effective translocation of azadirachtin, low toxicity to nonphytophagous natural enemies, and deterrence to adult beetles makes azadirachtin a viable control option that needs to be explored (Duthie-Holt et al., 1999; Held et al., 2001).

A recent study has demonstrated that imidacloprid and azadirachtin had both antifeedant and toxic effects against the Asian long-horned beetle and cottonwood borer (Plectrodera scalator) when fed toxic diet and "have potential for use in management programs" (Poland et al., 2006). In this experiment, we examine the use of the two systemic insecticidesazadirachtin and imidacloprid-for use in managing Japanese beetles on roses, by themselves and in conjunction with a range of foliar insecticides.

\section{Materials and methods}

Field and laboratory insecticide trials were conducted at the Meigs Research Farm (U.S. Department of
Agriculture Plant Hardiness Zone 5), 10 miles southeast of the Purdue University campus in West Lafayette, Ind., during Summer 2004. Bareroot floribunda-type roses (Bailey Nurseries, St. Paul, Minn.) were planted on 15 Apr. 2004 in four rows of 25 plants each in 1 -ft-deep and 1.5$\mathrm{ft}$-wide augered holes. Within each row, roses were placed $2 \mathrm{~m}$ apart, each row was $3 \mathrm{~m}$ apart and separated by a 2-m-wide strip of fescue turfgrass planted medially and mowed weekly to 4 inches. Plants received a minimum of 1 inch of water each week from either rain or drip-line irrigation. Drip irrigation and bare soil between turf strips were covered with a 2- to 4-inch layer of shredded hardwood mulch. Roses were maintained in accordance with standard growing practices (Lerner et al., 2003). It was unnecessary to apply fungicides to newly planted roses. $3.5 \mathrm{~g}$ of Garden Mate 10N-8.8P-8.3K fertilizer (Greenview Lebanon Seaboard Corp., Lebanon, Penn.) was applied under the mulch of each rose bush once new growth reached 6 inches (5 May). Senesced blooms were deadheaded (removed) weekly to stimulate bloom production during the course of the season. The number of blooms removed was recorded each week.

Field insecticide trials. Field grown roses were grouped into a fixed-factor completely randomized design with six replicates. Plants in field plots were randomly assigned to the 10 insecticide treatments and an untreated control (Table 1). These treatments compared the effectiveness of soil-applied imidacloprid [ $1.43 \mathrm{~g} /$ plant a.i. (Merit 2.5G; Bayer, Trafalgar, Ind.)], soil and foliarapplied azadirachtin $[0.144 \mathrm{~g} /$ plant a.i. (soil) and $0.072 \mathrm{~g} \cdot \mathrm{L}^{-1}$ a.i. (foliar) (Azatrol EC 1.2\%; PBI Gordon, Kansas City, Mo.)], foliar-applied carbaryl [1.2 g. $\mathrm{L}^{-1}$ a.i. (Sevin Liquid; Bayer)], and soil applications followed by foliar applications at 2- and 4-week intervals (Table 1). All initial soil insecticide applications were made before annual adult Japanese beetle emergence. Foliar insecticides were applied to runoff with a carbondioxide-powered sprayer at pressure of 35 psi within 1 week after the first beetle was caught at the research farm in a Trécé Japanese beetle trap (Tanglefoot Co., Grand Rapids, Mich.) baited with a mixture of 3 phenethyl propionate : 7 eugenol : 3 geraniol (floral lure) and $(R, Z)-5$-(1-decenyl)dihydro-2(3H)-furanone (sex lure). Traps were placed $25 \mathrm{~m}$ outside the north and south side of the field on 2.5-m-tall stands to determine first beetle flight. Traps were removed after the first beetle was caught.

Visual estimates of defoliation and floral bloom damage were recorded by the same three observers throughout the season. Estimates were made to the nearest $5 \%$ of the total leaf area or bloom tissue consumed and the mean from all observers has been reported. Estimates occurred twice weekly after the initiation of adult beetle flight. Each week, the height and width of each shrub was measured and a qualitative estimate of plant fullness was assigned. Fullness was visually estimated by looking at a plant profile and determining the amount of light that was blocked by the foliage. Fullness ranks were based on percentage of the canopy that was filled with leaves using a 1 to 5 scale $(1 \leq 20 \%, 2=21 \%$ to $40 \%, 3=41 \%$ to $60 \%, 4=61 \%$ to $80 \%, 5>80 \%)$.

Means and standard errors of injury and size measurements were calculated for each treatment. Effects of the pesticide treatment, mode of pesticide application (foliar, soil, both, and untreated) and timing of foliar application on these measures (weekly, biweekly, every 4 weeks, and none) were tested in one-way analyses of variance [ANOVAs (PROC GLM; SAS Institute, Cary, N.C.)]. All percentage data were arcsin square-root-transformed to correct for non-normality before analysis (Zar, 1999). When significant effects were detected in an ANOVA and variances among treatments were not homogeneous, a Welch ANOVA (PROC GLM, HOVTEST WELCH; SAS Institute) was performed. Means were separated using a least-significant difference test $(P \leq 0.05)$.

LABORATORY INSECTICIDE TRIALS. Trials were conducted on the foliage of field-grown roses that were protected from beetle injury with exclusion cages placed around selected plants at Meigs Research Farm before beetle emergence. The cages were made of $2.5-\mathrm{cm}$ hexagonal steel mesh tied together to form a cylinder. Cylinders were staked to the 
Table 1. Insecticide treatment effects as well as mode of insecticide delivery effects on defoliation and bloom damage of 'Acadia Sunrise' roses by Japanese beetles in 2004 .

\begin{tabular}{|c|c|c|c|}
\hline Insecticide treatments $^{\mathrm{z}}$ & $\begin{array}{c}\text { Defoliation, } 5 \text { Aug. } \\
{[\text { mean } \pm \text { SE }(\%)]}\end{array}$ & $\begin{array}{c}\text { Mean bloom } \\
\text { damage, } 8 \text { July } \\
{[\text { mean } \pm \text { SE }(\%)]}\end{array}$ & $\begin{array}{c}\text { Mean bloom } \\
\text { damage, } 5 \text { Aug. } \\
{[\text { mean } \pm \text { SE }(\%)]}\end{array}$ \\
\hline Untreated & $22.3 \pm 9.7 \mathrm{a}^{\mathrm{y}}$ & $30.1 \pm 18.1 \mathrm{a}^{\mathrm{y}}$ & $20.0 \pm 12.3 \mathrm{a}^{\mathrm{y}}$ \\
\hline Aza. soil + Carb. foliar 4 & $5.9 \pm 2.0 \mathrm{~b}$ & $1.8 \pm 0.9 b$ & $6.6 \pm 6.7 \mathrm{ab}$ \\
\hline Aza. foliar weekly & $4.8 \pm 4.0 \mathrm{~b}$ & $13.3 \pm 9.9 b$ & $4.3 \pm 1.9 \mathrm{ab}$ \\
\hline Imid. soil + Aza. foliar 2 & $1.8 \pm 1.0 \mathrm{~b}$ & $7.4 \pm 6.3 b$ & $2.1 \pm 1.9 \mathrm{ab}$ \\
\hline Imid. soil + Aza. foliar 4 & $1.1 \pm 1.1 \mathrm{~b}$ & $2.3 \pm 1.6 \mathrm{~b}$ & $0.2 \pm 0.2 \mathrm{~b}$ \\
\hline Aza. soil + Carb. foliar 2 & $0.3 \pm 0.2 \mathrm{~b}$ & $1.7 \pm 1.7 \mathrm{~b}$ & $0.3 \pm 0.2 \mathrm{~b}$ \\
\hline Imid. soil & $0.2 \pm 0.2 \mathrm{~b}$ & $1.1 \pm 0.4 \mathrm{~b}$ & $1.8 \pm 1.6 \mathrm{ab}$ \\
\hline Carb. foliar weekly & $0.0 \pm 0.0 \mathrm{~b}$ & $0.0 \pm 0.0 \mathrm{~b}$ & $0.0 \pm 0.0 \mathrm{~b}$ \\
\hline \multicolumn{4}{|l|}{ Mode of application } \\
\hline Soil & $1.2 \pm 0.9 \mathrm{~b}$ & $8.3 \pm 7.2 \mathrm{a}$ & $5.52 \pm 2.6 \mathrm{~b}$ \\
\hline
\end{tabular}

${ }^{\mathrm{z}}$ Insecticide treatments of imidacloprid (Imid.), azadirachtin (Aza.), and carbaryl (Carb.) were applied as foliar and soil treatments alone and in combination with each other as indicated $\left(\mathrm{g}=0.0353 \mathrm{oz}, \mathrm{lg} \cdot \mathrm{L}^{-1}=0.1335 \mathrm{oz} / \mathrm{gal}\right)$. Imidacloprid was applied to the soil at a rate of $1.43 \mathrm{~g} / \mathrm{plant}$ a.i. on $\mathrm{l} \mathrm{June} \mathrm{(soil).} \mathrm{Azadirachtin} \mathrm{was} \mathrm{applied} \mathrm{to} \mathrm{the} \mathrm{soil} \mathrm{at} \mathrm{a}$ rate of $0.144 \mathrm{~g} /$ plant a.i. on $22 \mathrm{June}$ (soil). Carbaryl was applied as a foliar spray at a rate of $1.2 \mathrm{~g} \cdot \mathrm{L}^{-1}$ a.i. at three different frequencies: once every week (foliar weekly), once every 2 weeks (foliar 2), and once every 4 weeks (foliar 4 ). Azadirachtin was applied as a foliar spray at a rate of $0.072 \mathrm{~g} \cdot \mathrm{L}^{-1}$ a.i. at three different frequencies: once every week (foliar weekly), once every 2 weeks (foliar 2), and once every 4 weeks (foliar 4 ).

${ }^{y}$ Means and SE followed by the same letter are not significantly different according to a least-significant difference test $(P>0.05)$.

ground with garden anchors and surrounded by mosquito netting (20 denier polyester fabric, $28 \mathrm{~g} \cdot \mathrm{m}^{-2}$; Gilford Fabric, Greensboro, N.C.). Caged plants were randomly interspersed among the field plot adhering to the randomized complete block design. Cage plant treatments were replicated six times to provide enough leaves for the trial. Same-aged leaves were collected from all plants studied on each day of the assay.

Laboratory trials assessed the deterrence of azadirachtin when applied at different rates as a soil systemic and foliar spray on 6 July 2004. The two soil treatments were applied at rates of 0.144 and $0.288 \mathrm{~g} /$ plant a.i. in $2 \mathrm{~L}$ of water per plant. The foliar treatment was applied at a rate of $0.072 \mathrm{~g} \cdot \mathrm{L}^{-1}$ a.i. to runoff. Six replicates were used for each treatment. Leaves collected from these plants at $1,4,7,14,21$, and $28 \mathrm{~d}$ after application were subject to a choice test. A single leaf with five intact leaflets from one of the selected treatments was assayed next to an untreated leaf with five intact leaflets. Ten beetles were added to these leaves in a 14-cm-diameter and 2.5$\mathrm{cm}$-deep petri dish containing a 12.5$\mathrm{cm}$-diameter filter paper (Whatman International Ltd, Maidstone, U.K.) that was moistened with tap water. The beetles were allowed to feed on the leaves for $24 \mathrm{~h}$. Adult beetles used in this assay were collected from Japanese beetle traps within $16 \mathrm{~h}$ of trap placement.

The area of leaf tissue consumed in each petri dish was measured using images of leaves scanned before and after the assay with a UMAX Astra 1220S (UMAX Technologies, Dallas) flatbed scanner. Images were saved in True Color, RGB format at $200 \times 200$ pixels $(200 \mathrm{dpi})$, at a scale of $100 \%$ and saved in a tagged image file format (TIFF). Leaf area was estimated using Scion Image for Windows (Meyer Instruments and Scion Corp., Houston). Each leaf scan included a standard square card of known size to compensate for variation in scanner operation. The difference in leaf area consumed after $24 \mathrm{~h}$ was measured by subtracting the treated leaf area consumed from the untreated leaf area consumed.

Data for laboratory assays were analyzed in a randomized complete block ANOVA (PROC GLM; SAS Institute). Means of significant effects were separated using a Fisher's protected least-significant difference test $(P \leq 0.05)$.

\section{Results}

Injury to roses incited by Japanese beetles in 2004 was moderate.
Defoliation was detected on 28 June with little increase until peak expression on 5 Aug. when defoliation on untreated plants exceeded 20\% (Fig. 1). Bloom damage was highest in the early half of the season but varied throughout the season. Due to season long variation, two dates of peak injury 8 July (bloom damage) and 5 Aug. (bloom damage and defoliation) were selected for analysis.

Significant differences in defoliation were observed among insecticide treatments on 5 Aug. (Welch $F=4.05$; $\mathrm{df}=10,53 ; P=0.005)$. Variation in timing $(F=0.60 ; \mathrm{df}=1,60 ; P=0.62)$ did not significantly contribute to the effectiveness of foliar protection (Table 2). Variation in mode of application was significant $(F=3.95$; df $=$ 1,$60 ; P=0.012$ ) according to a standard ANOVA but was only marginally significant according the Welch ANOVA $(F=2.41$; df $=1$, $60 ; P=0.11)$. Roses receiving either soil or foliar applications of insecticide had lower levels of defoliation than the untreated controls. Bloom damage on 8 July was not significantly affected by kind of insecticide treatment $(F=1.09 ; \mathrm{df}=1,60 ; P=0.38)$, mode of insecticide application $(F=$ 2.25 ; df $=1,60 ; P=0.09)$, or variation in timing $(F=0.89 ; \mathrm{df}=1,60$; $P=0.44$ ) (Table 2 ). On the second peak of 5 Aug., bloom damage was 


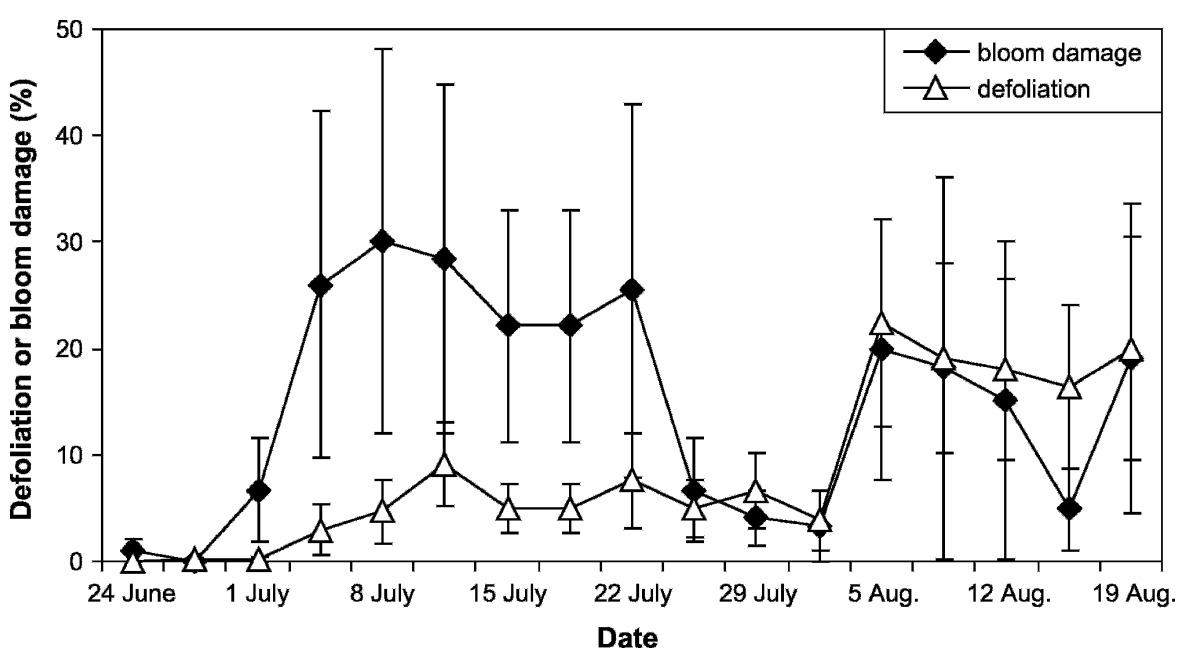

Fig. 1. Mean percent defoliation and damage to blooms of untreated control 'Acadia Sunrise' roses incited by adult Japanese beetles in 2004 (bars = SE).

Table 2. Insecticide treatments effects as well as mode of insecticide delivery effects on plant width, height, and form of 'Acadia Sunrise' roses by Japanese beetles on 19 Aug. 2004.

\begin{tabular}{lccc}
\hline Insecticide treatments $^{\mathrm{z}}$ & $\begin{array}{c}\text { Mean plant } \\
\text { width }(\mathbf{m m})^{\mathbf{y}}\end{array}$ & $\begin{array}{c}\text { Mean plant } \\
\text { height }(\mathbf{m m})^{\mathrm{y}}\end{array}$ & $\begin{array}{c}\text { Mean plant } \\
\text { form }(\mathbf{1 - 5})^{\mathbf{x}}\end{array}$ \\
\hline Imid. soil & $64.8 \pm 6.9 \mathrm{a}^{\mathrm{w}}$ & $65.0 \pm 6.6 \mathrm{a}$ & $3.0 \pm 0.3 \mathrm{a}$ \\
Carb. foliar weekly & $60.0 \pm 3.5 \mathrm{ab}$ & $66.0 \pm 3.5 \mathrm{a}$ & $3.0 \pm 0.4 \mathrm{a}$ \\
Aza. soil + Carb. foliar 2 & $57.0 \pm 1.5 \mathrm{ab}$ & $59.7 \pm 2.9 \mathrm{a}$ & $3.7 \pm 0.3 \mathrm{a}$ \\
Aza. soil + Carb. foliar 4 & $52.0 \pm 2.4 \mathrm{~b}$ & $61.5 \pm 3.8 \mathrm{a}$ & $3.3 \pm 0.3 \mathrm{a}$ \\
Aza. soil & $51.4 \pm 5.6 \mathrm{~b}$ & $44.2 \pm 4.8 \mathrm{a}$ & $3.2 \pm 0.2 \mathrm{a}$ \\
Aza. foliar weekly & $49.8 \pm 4.9 \mathrm{~b}$ & $48.7 \pm 3.2 \mathrm{a}$ & $2.2 \pm 0.4 \mathrm{a}$ \\
Imid. soil + Aza. foliar 4 & $49.5 \pm 3.7 \mathrm{~b}$ & $58.3 \pm 6.1 \mathrm{a}$ & $2.8 \pm 0.2 \mathrm{a}$ \\
Imid. soil + Aza. foliar 2 & $49.3 \pm 5.2 \mathrm{~b}$ & $56.5 \pm 5.1 \mathrm{a}$ & $2.2 \pm 0.3 \mathrm{a}$ \\
Aza. soil + Aza. foliar 4 & $49.2 \pm 3.1 \mathrm{~b}$ & $55.0 \pm 7.8 \mathrm{a}$ & $4.5 \pm 0.3 \mathrm{a}$ \\
Aza. soil + Aza. foliar 2 & $48.2 \pm 1.7 \mathrm{~b}$ & $50.8 \pm 4.3 \mathrm{a}$ & $3.2 \pm 0.3 \mathrm{a}$ \\
Untreated & $46.8 \pm 4.3 \mathrm{~b}$ & $53.0 \pm 5.5 \mathrm{a}$ & $3.0 \pm 0.4 \mathrm{a}$ \\
Mode of application & & & \\
$\quad$ Soil & $58.7 \pm 4.8 \mathrm{a}$ & $55.6 \pm 5.2 \mathrm{a}$ & $3.1 \pm 0.2 \mathrm{a}$ \\
$\quad$ Foliar & $53.9 \pm 3.5 \mathrm{~b}$ & $55.6 \pm 3.6 \mathrm{a}$ & $2.5 \pm 0.3 \mathrm{a}$ \\
$\quad$ Soil and foliar & $50.9 \pm 1.3 \mathrm{~b}$ & $56.9 \pm 2.1 \mathrm{a}$ & $3.3 \pm 0.2 \mathrm{a}$ \\
$\quad$ Untreated & $46.8 \pm 4.3 \mathrm{~b}$ & $53.0 \pm 5.5 \mathrm{a}$ & $3.0 \pm 0.4 \mathrm{a}$ \\
\hline
\end{tabular}

${ }^{2}$ Insecticide treatments of imidacloprid (Imid.), azadirachtin (Aza.), and carbaryl (Carb.) were applied as foliar and soil treatments alone and in combination with each other as indicated $\left(\mathrm{lg}=0.0353 \mathrm{oz}, \mathrm{lg} \cdot \mathrm{L}^{-1}=0.1335 \mathrm{oz} / \mathrm{gal}\right)$. Imidacloprid was applied to the soil at a rate of $1.43 \mathrm{~g}$ /plant a.i. on 1 June (soil). Azadirachtin was applied to the soil at a rate of $0.144 \mathrm{~g} /$ plant a.i. on 22 June (soil). Carbaryl was applied as a foliar spray at a rate of $1.2 \mathrm{~g} \cdot \mathrm{L}^{-1}$ a.i. at three different frequencies: once every week (foliar weekly), once every 2 weeks (foliar 2), and once every 4 weeks (foliar 4). Azadirachtin was applied as a foliar spray at a rate of $0.072 \mathrm{~g} \cdot \mathrm{L}^{-1}$ a.i. at three different frequencies: once every week (foliar weekly), once every 2 weeks (foliar 2 ), and once every 4 weeks (foliar 4 ).

${ }^{y}$ Due to variability in plant shape, the greatest length and width were recorded for each plant $(1 \mathrm{~mm}=0.0394 \mathrm{inch})$. xPlant form is a canopy fullness rank on a $1-5$ scale, with $1=$ the least full canopy of leaves and $5=$ a completely full canopy ( $1 \leq 20 \%, 2=21 \%$ to $40 \%, 3=41 \%$ to $60 \%, 4=61 \%$ to $80 \%, 5>80 \%$ ).

"Means and SE followed by the same letter are not significantly different according to Fisher's protected LSD test $(P>0.05)$.

marginally affected by kind of insecticide treatment according to the standard ANOVA $(F=1.83 ; \mathrm{df}=1$, $60 ; P=0.08)$. Mode of insecticide application did not affect bloom damage $(F=1.45 ; \mathrm{df}=1,60 ; P=0.24)$. Variation in timing $(F=0.60 ; \mathrm{df}=1$, $60 ; P=0.62)$ did not significantly contribute to the effectiveness of bloom protection (Table 2 ).
$P=0.72$ and $F=0.03, \mathrm{df}=1,52$, $P=0.85$; respectively).

In laboratory choice tests, beetles showed no significant preference for feeding on azadirachtin-treated compared with untreated leaves during tests conducted between 1 and $7 \mathrm{~d}$ after treatments were applied (Fig. 2). A significant preference for untreated foliage occurred on day 14 $(F=4.92 ; \mathrm{df}=2,10 ; P=0.03)$, day $21(F=6.04 ; \mathrm{df}=2,10 ; P=0.02)$, and day $28(F=6.85 ; \mathrm{df}=2,10 ; P=$ $0.01)$ after application.

\section{Discussion}

Our study compares effectiveness of selected insecticides for managing Japanese beetles in a year where levels of bloom damage and defoliation in untreated plots were moderate but above the general $10 \%$ injury level considered unacceptable by consumers (Sadof and Sclar, 2002) (Fig. 1). All insecticide treatments suppressed defoliation to $<10 \%$, regardless of mode of application. As such, under these levels of defoliation there was no advantage to using any particular insecticide when applied as a soil systemic, foliar spray, or in combination (Table 2).

Deterrence of high and low concentrations of azadirachtin in laboratory assays between 14 and $28 \mathrm{~d}$ supports what was observed in the field studies (Fig. 2, Table 2). Azadirachtin applied to the soil 1 month before beetle emergence kept defoliation $<10 \%$ throughout the entire field season. Levels of foliar protection achieved by the antifeedant properties of soil-applied azadirachtin were similar to that achieved by the toxicant properties of imidacloprid. Effective protection of foliage by a single systemic application of imidacloprid supports previous studies (Sclar and Cranshaw, 1996; Webb et al., 2003). Azadirachtin appears to have substantial systemic activity in leaves in this study, and this is consistent with previous studies conducted on both woody and herbaceous plants (Arpaia and van Loon, 1992; Duthie-Holt et al., 1999; Nisbet et al., 1993) (Table 2). Addition of foliar sprays to soil applied insecticides provided no added benefit compared with soil applications of azadirachtin alone (Table 2).

Weekly applications of carbaryl gave the best protection of blooms 


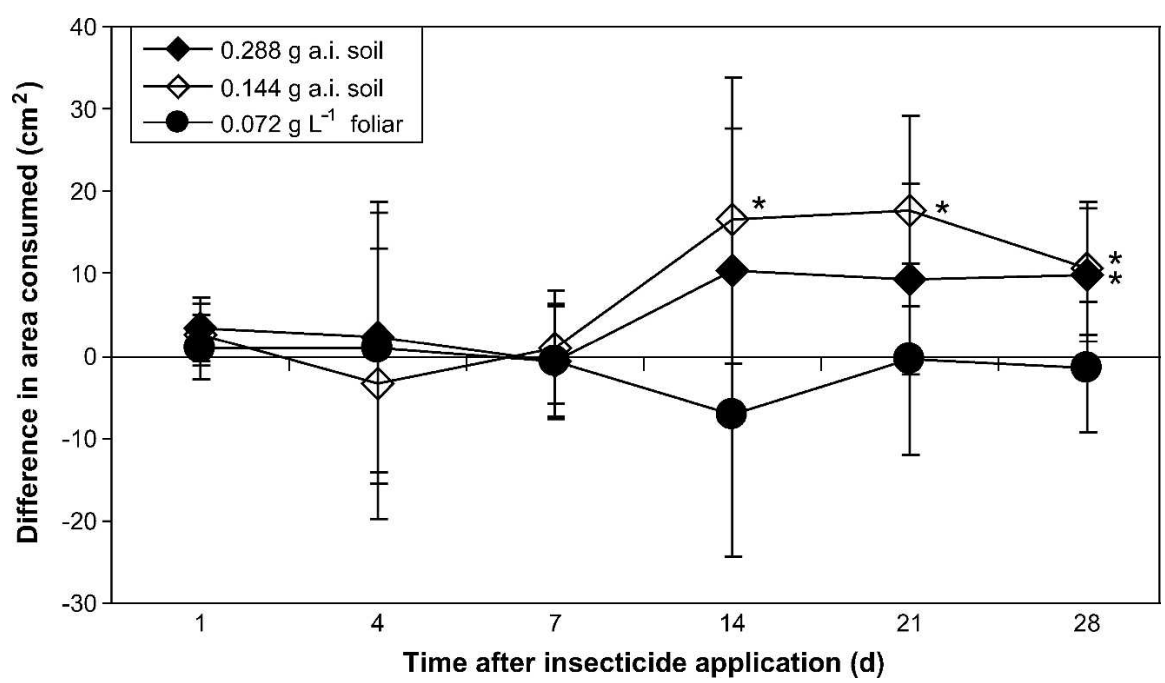

Fig. 2. Differences in leaf area $\left(1 \mathrm{~cm}^{2}=0.1550 \mathrm{inch}^{2}\right)$ consumed by Japanese beetles in choice tests of treated and untreated rose foliage. Roses were treated with soil applications of azadirachtin at one of two rates [0.144 or 0.288 $\mathrm{g} /$ plant a.i. $(1 \mathrm{~g}=\mathbf{0 . 0 3 5 3} \mathrm{oz})]$ or with foliar applications of azadirachtin at one rate $\left[0.072 \mathrm{~g} \cdot \mathrm{L}^{-1}\right.$ a.i. $\left.\left(1 \mathrm{~g} \cdot \mathrm{L}^{-1}=0.1335 \mathrm{oz} / \mathrm{gal}\right)\right]$. Bars represent Fisher's protected least-significant differences. Data points with an asterisk are significantly different from zero.

(Table 2). Adding carbaryl foliar treatments every 2 weeks to plants receiving soil applications of azadirachtin improved control to the level achieved with weekly foliar carbaryl applications. Foliar applications of azadirachtin gave no added protection to blooms of plants treated with imidacloprid. Azadirachtin as a soil, foliar, or combined application gave inconsistent results for bloom protection. At high levels of bloom injury, neither soil treatment by itself protected blooms on either analysis date.

This study does not make a particularly good case for applying either azadirachtin or imidacloprid to the soil to protect rose blooms. Bloom damage of plants treated with soil azadirachtin alone or with a foliar insecticide varied from $1.7 \%$ to $16.9 \%$ on 8 July (Table 2 ) and from $0.2 \%$ to $18.4 \%$ on 5 Aug. (Table 2 ). Imidacloprid, with or without a foliar insecticide, provided slightly, but not always significantly, better bloom protection throughout the season with a much smaller range in injury of $0.2 \%$ on 5 Aug. to $7.4 \%$ on 8 July (Table 2). The observed levels of feeding on imidacloprid-treated blooms do not confirm the reported ineffectiveness of this material as a bloom protectant seen with western flower thrips and Transvaal daisy in a previous study (Cloyd and Sadof, 1998). As such, neither material when applied to the soil can provide reliable bloom protection.

Plant size was not significantly affected by soil-insecticide treatments (Table 2). Plant height was not adversely affected by insecticide treatments; none of the treated plants was $>10 \mathrm{~cm}$ shorter than the untreated plants. All roses treated with insecticides had a width larger than the untreated plants. Insecticides used in this study showed no evidence of causing phytotoxicity.

In conclusion, single soil applications of imidacloprid and azadirachtin or weekly foliar applications of azadirachtin provide adequate foliage protection under moderate levels of defoliation. Although foliage of plants treated with soil-applied azadirachtin alone was protected from beetle injury, damage to blooms was unacceptable. Given the previous inability of imidacloprid to protect blooms under higher levels of Japanese beetle pressure (Vitullo, 2004), the value of soil-applied insecticides to protect roses from Japanese beetles may be limited.

\section{Literature cited}

Arpaia, S. and J.J.A. van Loon. 1993. Effects of azadirachtin after systemic uptake into Brassica oleracea on larvae of Pieris brassicae. Entomol. Exp. Appl. 66:39-45.
Cloyd, R.A. and C.S. Sadof. 1998. Flower quality, flower number, and western flower thrips density on Transvaal daisy treated with granular insecticides. HortTechnology 8:567-570.

Duthie-Holt, M.A., J.H. Borden, and L.J. Rankin. 1999. Translocation and efficacy of neem-based insecticide in lodgepole pine using Ipspini (Coleoptera: Scolytidae) as an indicator species. J. Econ. Entomol. 92:180-186.

Held, D.W., T. Eaton, and D.A. Potter. 2001. Potential for habituation to a neem-based feeding deterrent in Japanese beetles, Popillia japonica. Entomol. Exp. Appl. 101:25-32.

Held, D.W. and D.A. Potter. 2004. Floral affinity and benefits of dietary mixing with flowers for a polyphagous scarab, Popillia japonica Newman. Oecologia 140:312-320.

Isman, M.B., O. Koul, J.T. Arnason, J. Stewart, and G.S. Salloum. 1991. Developing a neem-based insecticide for Canada. Mem. Entomol. Soc. Can. 159: 39-47.

James, D.G. and J. Coyle. 2001. Which pesticides are safe to beneficial insects and mites? Agr. Environ. News 178:12-14.

James, D.G. and B. Vogele. 2001. The effect of imidacloprid on survival of some beneficial arthropods. Plant Protection Quarantine 16:58-62.

Ladd, T.L., Jr., M. Jacobson, and C.R. Buriff. 1978. Japanese beetles: extracts from neem tree seeds as feeding deterrents. J. Econ. Entomol. 71:810-813.

Ladd, T.L., Jr., J.D. Warthen, Jr., and M.G. Klein. 1984. Japanese beetle (Coleoptera: Scarabaeidae): the effects of azadirachtin on the growth and development of the immature forms. J. Econ. Entomol. 77:903-905.

Lawson, A.B. and D.L. Dahlsten. 2003. Evaluation of systemic insecticides as a treatment option in integrated pest management of the elm leaf beetle, Xanthogaleruca luteola (Muller) (Coleoptera: Chrysomelidae). J. Econ. Entomol. 96:1455-1462.

Lerner, B.R., M.N. Dana, C.S. Sadof, R. Cloyd, and P. Pecknold. 2003. Roses. 8 Apr. 2003. <http://www.hort. purdue.edu/ext/HO-128.pdf>.

Naumann, K., L.J. Rankin, and M.B. Isman. 1994. Systemic action of neem seed extract on mountain pine beetle (Coleoptera: Scolytidae) in lodgepole pine. J. Econ. Entomol. 87:1580-1585.

Nisbet, A.J., J.A.T. Woodfor, R.H. Strang, and J.D. Connolly. 1993. Systemic antifeedant effects of azadirachtin 
on the peach-potato aphid Myzus persicae. Entomol. Exp. Appl. 68:87-98.

Poland, T.M., R.A. Haack, T.R. Petrice, D.L. Miller, and L.S. Bauer. 2006. Laboratory evaluation of the toxicity of systemic insecticides for control of Anoplophora glabripennis and Plectrodera scalator (Coleoptera: Cerambycidae). J. Econ. Entomol. 99:85-93.

Potter, D.A. and D.W. Held. 2002. Biology and management of the Japanese beetle. Annu. Rev. Entomol. 47:175-205.

Raupp, M.J., R.E. Webb, A. Szczepaniec, D. Booth, and R. Ahern. 2004. Incidence, abundance, and severity of mites on hemlocks following applications of imidacloprid. J. Arboricult. 30:108-113.

Rebek, E.J. and C.S. Sadof. 2003. Effects of pesticide applications on the euonymus scale (Homoptera: Diaspididae) and its parasitoid, Encarsia citrine (Hymenoptera: Aphelinidae). J. Econ. Entomol. 92:446-452.
Sadof, C.S. and D.C. Sclar. 2002. Public tolerance to defoliation and flower distortion in a public horticulture garden. J. Econ. Entomol. 95:348-353.

Schmutterer, H. 1990. Properties and potential of natural pesticides from the neem tree, Azadirachta indica. Annu. Rev. Entomol. 35:271-297.

Sclar, D.C. and W.S. Cranshaw. 1996. Evaluation of new systemic insecticides for elm insect control. J. Environ. Hort. $14: 22-26$.

Sclar, D.C., D. Gerace, and W.S Cranshaw. 1998. Observations on population increases and injury by spider mites (Acari: Tetranychidae) on ornamental plants treated with imidacloprid. J. Econ. Entomol. 91:250-255.

Smith, S.F. and V.A. Krischik. 1999. Effects of systemic imidacloprid on Coleomegilla maculata (Coleoptera: Coccinellidae). Environ. Entomol. 28:1189-1195.
U.S. Environmental Protection Agency. 2003. 1998-1999 Pesticide market estimates: usage. 12 Sept. 2003. <http:// www.epa.gov/oppbeadl/pestsales/ 99pestsales/usage1999_3html>.

Vitullo, J.M. 2004. Cultural and chemical controls of adult Japanese beetles (Coleoptera: Scarabaeidae) on roses for home gardens. Purdue Univ., West Lafayette, Ind., MS Thesis.

Wang, B., R. Gao, V.C. Mastro, and R.C. Reardon. 2005. Toxicity of four systemic neonicotinoids to adults of Anoplophora glabripennis (Coleoptera: Cerambycidae). J. Econ. Entomol. 98:2292-2300.

Webb, R.A., J.R. Frank, and M.J. Raupp. 2003. Recovery of eastern hemlock from attack by hemlock woolly adelgid following treatment with imidacloprid. J. Arboriculture 29:298-302.

Zar, J.H. 1999. Biostatistical analysis. 4th ed. Prentice Hall, Upper Saddle River, N.J. 